\title{
Documentação de línguas e culturas indígenas
}

\section{Documentation of indigenous languages and cultures}

\author{
Eliane CAMARGO* \\ Instituto Francês de Estudos Andinos (IFEA), Associação Ipê \\ Asiwae WAYANA \\ Mudu KAXINAWA
}

\begin{abstract}
RESUMO: Nos últimos vinte anos, instituições acadêmicas nacionais e internacionais, Fundações culturais e ONGs têm fomentado a preservação de culturas e línguas ameaçadas de extensão em um futuro próximo. O mundo conta com um pouco mais de 6000 línguas, vinte e cinco das quais desaparecem anualmente. As línguas ameríndias, sobretudo as amazônicas, estão na fila. Diferentes esforços lutam em prol de uma política indiscriminável pelo direito de "existir, mantendo sua dignidade sociocultural e linguística, independentemente de suas origens étnicas." O presente texto apresenta algumas dessas ações, dentro do âmbito da documentação de três culturas e línguas indígenas: caxinauá, aparai e wayana.
\end{abstract}

PALAVRAS-CHAVE: Patrimônio cultural imaterial. Línguas indígenas em perigo. Aparai. Caxinauá. Wayana.

\begin{abstract}
In the last twenty years, international and national academic institutions, cultural foundations and NGOs have been promoting the preservation of cultures and languages in danger of extinction in the near future. Of the approximately 6,000 languages in the world twenty-five disappear each year. Amerindian languages, especially Amazonian, are highly endangered. Different efforts are being made to establish a non-discriminatory policy for the right of "existence, preserving one's socio-cultural and linguistic dignity regardless of one's ethnic origin". This paper presents some of these measures in the context of the documentation of three indigenous cultures and languages: Apalai, Cashinahua and Wayana.
\end{abstract}

KEYWORDS: Intangible Cultural Heritage. Indigenous Endangered Languages. Apalai. Cashinahua. Wayana.

\footnotetext{
*Pesquisador associado ao Instituto Francês de Estudos Andinos (IFEA). Coordenadora de projetos na Ipê - Associação para o diálogo intercultural: pesquisa e ação (http://ipe-recherche-action.org/). Asiwae Wayana e Mudu Kaxinawa vêm trabalhando na reflexão do sistema linguístico de suas línguas.

Meus sinceros agradecimentos aos comentários que recebi de Sabine Reiter, Edilene Coffaci de Lima e Denise Fajardo sobre a questão de documentação de línguas e culturas ameaçadas abordada neste texto. Um agradecimento especial a Ana Yano por de ter sido uma interlocutora bastante atenciosa durante diferentes fases da elaboração deste texto. Os agradecimentos vão também aos pareceristas.
} 


\section{Introdução}

Nos últimos trinta anos, houve um grande avanço no campo da antropologia linguística voltado à documentação de línguas faladas por poucos locutores.A sua documentação é de relevância não apenas para o grupo referenciado, mas como patrimônio da humanidade por revelar aspectos tipológicos distintos de tantas outras línguas, traduzindo por meio da expressão oral modos de pensar, e estruturas linguísticas próprias para expressar tal modo. Vejamos o caso de uma língua pano, o caxinauá que não dispõe lexicalmente de cópula. A inexistência lexical dos verbos "ser" e "estar" não deixam lacunas na forma de expressão, indicando "existência". Seus locutores usam outras estratégias gramaticais para expressar tais conceitos, o uso de diferentes classes de assertivos predicam o lexema, e este mesmo sem o assertivo revela ser onipredicativo. O interessante é entender quais são essas estratégias. Essas riquezas gramaticais, revelando um semantismo hors pair, são ainda pouco conhecidas das mais diversas línguas indígenas faladas no Brasil que, de acordo com o IBGE (Censo 2010), são 305 etnias indígenas, falantes de 274 idiomas, mantendo viva a cultura de povos originários no Brasil.

Cabe, no entanto, assinalar queo campo voltado à pesquisa linguística tem tendência a ser apreendido tanto como uma pesquisa "desagradável" para os não linguistas, quanto carregado de uma imagem depreciativa entre muitos dos locutores da língua estudada: "que coisa chata falar só de fonema e de morfema", enunciam alguns colegas antropólogos. Outros, ao contrário, expressam uma certa tristeza em não conseguir diálogo interdisciplinar. Ora, toda pesquisa tem seus encantos e desencantos, seja em relação ao grupo, seja em relação à metodologia de trabalho; seja, ainda, quanto aos resultados obtidos. O presente texto apresenta um panoramade uma dessas facetas da pesquisa de campo: aquela ligada à pesquisa prático-científica no âmbito da documentação de cultura e língua ameríndia que venho realizando junto a três grupos indígenas da Amazônia: aparai, wayana (línguas caribes) e caxinauá (língua pano). 


\section{Documentação de cultura e língua}

A grande maioria das quase sete mil línguas do mundo é falada por um número pequeno de pessoas, sendo que metade delas corre um sério risco de se tornar, em um futuro próximo, apenas dados históricos dos arquivos do patrimônio da humanidade. $\mathrm{O}$ próprio homem é um dos responsáveis potenciais desse risco e, segundo a UNESCO, uma língua desaparece a cada quinze dias e vinte cinco línguas apagam-se anualmente. Dado gravíssimo para o patrimônio imaterial, sobretudo em vista que a quase totalidade das línguas pertence às sociedades ditas de tradição oral, numericamente minoritárias. Nos últimos vinte anos, forças intelectuais e civis, em uma perspectiva de "salvaguarda de cultura e línguas ameaçadas", colocaram à disposição da pesquisa científica condições materiais em torno de um objetivo comum: "documentar exaustivamente línguas consideradas em perigo iminente de extinção". Neste objetivo muita gente confere à língua falada por uma pequena comunidade o maior perigo. Isto é um fato indiscutível. Uma língua falada por menos de cem pessoas em meio a uma sociedade nacional com milhões de falantes de uma língua majoritária, torna-se, de fato, um náufrago potencialmente iminente. Tal situação pode ser revertida, ainda que a ameaça de extinção persista.

No Brasil, grupos do Xingu, como o aweti e o trumai, ou o aparai e o wayana, no extremo norte do Pará, são exemplos. Os dois primeiros beneficiaram-se do programa DoBeS de documentação de línguas em perigo, com financiamento da Fundação Volkswagen $^{1}$ (cf. http://dobes.mpi.nl/projects/cashinahua/project). Cabe ressaltar que a situação da prática linguística entre os grupos aweti e trumai não é a mesma. Os primeiros, pertencentes à família tupi, contam com menos de duzentos indivíduos falantes de sua língua de origem, ao passo que os trumai (família isolada) - sobretudo os mais jovens - quase não a falam mais. No que diz respeito aos aparai e wayana, estes ainda não receberam a devida atenção quanto ao perigo de suas línguas se extinguirem dentro de algumas décadas. No caso desses grupos caribes situados em território

\footnotetext{
1 "Projeto de documentação de cultura e língua caxinauá", financiado pela Fundação Volkswagen, 20062011, e vinculado ao Instituto Max Planck (MPI-EVA) de Leipzig (Alemanha) e ao LESC-CNRS (França).
} 
brasileiro, a língua wayana, numericamente superior à aparai, apresenta maior tendência ao desaparecimento devido à política linguística adotada e aplicada no território tradicionalmente wayana. Desde a década de sessenta, apoiados pelo governo brasileiro, missionários do Instituto de Linguística de Verão (ILV) passaram a atuar entre esses grupos e optaram por uma escola em aparai, desenvolvendo, assim, a alfabetização na referida língua, tendo como objetivo principal a difusão de conceitos cristãos, como a leitura da Bíblia em apalai. Tais missionários apoiaram igualmente um programa de desenvolvimento econômico aparai, proporcionando a este grupo certa notoriedade dentro e fora da área, visto que passaram a controlar um novo sistema econômico baseado na introdução de um comércio de mercadorias industrializadas, diminuindo, em contrapartida, a expressão socioeconômica e linguística do grupo wayana naquele que é, por eles considerado, seu território tradicional.

Outros grupos amazônicos podem apresentar uma situação discutível quanto ao atributo de "necessitar uma documentação da língua", dado seu número de falantes. No entanto, o foco não me parece dever recair sobre a proporção numérica de falantes, mas sim nas condições gerais da transmissão dos saberes e da língua. Isto nos remete a uma questão cara à etnolinguística, a saber, aquela que diz respeito à relação entre cultura e língua. Esse texto divide-se em duas partes: A primeira parte volta-se para um dos resultados de oficinas de "estudo reflexivo" sobre o funcionamento morfossemântico de alguns aspectos linguísticos. Optou-se pela relação entre o elemento possuidor e o seu elemento possuído em wayana e pela interpretação da animacidade do elemento vegetal transformado em caxinauá, mostrando interfaces entre língua e cultura. A segunda parte apresenta Programas de documentação nos quais as oficinas acima foram realizadas.

\section{Língua e cultura}

A etnolinguística consiste em estudar 'fatos da língua' levando em conta pontos de vista pluridisciplinar: linguístico e etnológico. Uma análise linguística pode ser efetuada com auxílio de diferentes disciplinas, seja de forma unilateral (fonologia, sintaxe, léxico) ou multilateral com interfaces (fonologia-sintaxe, fonologia-léxico). Há pouco mais de trinta anos, no edital inaugural da revista Amerindia, o semanticista Bernard Pottier (1976) expunha os pontos relevantes do estudo da etnoliguística, todos 
de ordem tipológica: tipologia sintática, semântica, textual, proxêmica e a do significante, esta última referindo-se aos gestos e atitudes (comunicação não verbal) ${ }^{2}$. Ainda que a etnolinguística não constitua um campo novo, ainda é pouco abordada em seu princípio interdisciplinar, notadamente no que diz respeito aos grupos e línguas ameríndias da Amazônia. A tipologia linguística certamente tem sido bastante analisada, sobretudo por uma nova leva de jovens linguistas brasileiros, porém um olhar no contexto cultural do grupo ainda é pouco levado em consideração em muitos dos trabalhos descritivos.

\section{A semântica cultural expressa na língua}

O Wayana - língua caribe falada por cerca de 2.200 pessoas em uma vasta zona de fronteira tripartite: Brasil, Guiana francesa e Suriname. Os dados aqui apresentados foram coletados no Brasil e na Guiana francesa, onde vou anualmente em um ou em outro desses países desde $1993^{3}$.

\subsection{Inalienável, alienável e inerente}

A carência de um olhar interdisciplinar no contexto cultural do grupo recai em certos aspectos da análise linguística. Encontrar as formas da língua e glosá-las linguisticamente não bastam para revelar a expressão semântica que uma simples forma pode veicular. Falar, por exemplo, de posse inerente, alienável ${ }^{4}$ e inalienávelnão é suficiente para apreender o que a teoria linguística poderia dizer a respeito de tal classificação nativa. Vejamos o que nos revela a morfologia de construção de posse em wayana.

Relação de inerência - A relação de inerência não recebe nenhum morfema específico que caracterize tal relação entre o elemento possuidor e o elemento possuído. Alguns termos de parentesco, como os genitores (pai e mãe) advêm de uma relação de inerência:

\footnotetext{
${ }^{2}$ Estudo da utilização do espaço pelos seres humanos e os animais em sociedade.

${ }^{3}$ Estudo realizado para este artigo em colaboração com Asiwae Wajana.

${ }^{4}$ Elemento dependente do possuidor: partes do corpo humano ('a mão de Pedro'), família consanguínea ('o filho de Pedro').
} 
Jumï 'genitor', -je 'genitora' - relação inerente,
1a. $\ddot{i}-j u m$
n-umëk

1POSS ${ }^{5}$-genitor.INAL 3U-chegar.COMPL

'O meu pai chegou.'

1b. İ-jumï-mna man ïmë pona n-їtëm

1POSS-genitor.INER-PRIV EXIST roçado ablativo 3U-ir.COMPL

'O meu pai não está por ter ido à roça' (mas está por perto)

1c. $i$-jumï-mna $\quad w-a-i \quad$ talë

3POSS-genitor.INER-PRIV 1A3P-ser/estar-MOD aqui

'Estou sem o meu pai.' (lit. que faleceu/que não está por perto/que está em outro lugar)

Observamos, nos enunciados acima, três aspectos morfossemânticos:

a) a ausência de morfologia específicando a relação de inerência;

b) o elemento possuído indicializado pela 1a. (e 2a.) pessoa requer o predicado existencial, man. Essa estrutura requer uma leitura epistêmica: o elemento possuidor não dispõe naquele momento do elemento possuído. Porém ele existe e está espacialmente próximo;

c) o elemento possuído indicializado pela 3a. pessoa requer a copula, indicializada pela 1a. (e 2a.) pessoa. Essa estrutura requer igualmente uma leitura epistêmica: o elemento possuidor não dispõe do elemento possuído ou por existir e não estar próximo (espacialmente), ou por não existir mais, como é o caso de falecimento.

Vejamos uma outra série de exemplos com o termo wanë 'abelha, mel', que não recebe nenhum tratamento morfológico especificando a relação semântica entre os elementos possuidor-possuído. Duas construções negativas são usadas: uma delas é

\footnotetext{
${ }^{5}$ Abreviação :1 primeira pessoa; 2 segunda pessoa; 3 terceira pessoa; A agente; ABL ablativo; ALIEN alienável; ASS assertivo; COMPL aspecto complete; DIR direcional; EVOL aspecto evolutivo; EXIST existencial; i.p. índice pessoal; INAL inalienável; INCOMPL aspecto incompleto; INERinerência; lit. literal; LOC locativo; MOD modalidade (epistêmica, cognitiva); NEG negação; NMZR nominalizador; P paciente; POSS possessivo; PRIV privativo; REFL reflexivo; U actante único.
} 
marcada pelo privativo -mna que remete a um elemento possuidor que não dispõe do produto para a venda por exemplo (2a). A outra é marcada pelo sufixo denegação -la que remete à abelha (como element possuidor) que não produziu (ainda) mel (que é inerenteao seu produto) $(2 b)$ :

2a. wanë-mna $\quad w-a-i$

mel.INER-PRIV 1A3P-ser/estar-MOD

'Não tenho mel (para vender).'

2b. i-wanë-la

man hemalë

3POSS-mel.INER-NEG EXIST agora/hoje/nesse momento

'Ela (, abelha,) não tem mel.'

Relação de inalienabilidade - Os termos de parentesco que marcam uma relação biológica (avós, filhos, netos) ou classificatória têm a sua inalienabilidade marcada pelo sufixo $-l i ̈ /-l u^{6}$. Este aparece apenas em construções negativas (3b-c), salvo em um dos termos de parentesco que veremos adiante:
3a. j-emsi
etomamï-la-hnë
man
1POSS-filha.INAL acordar-NEG- ainda EXIST
'A minha filha ainda não acordou.'

3b. j-emsi-lï-mna man t-ïnot malë

1POSS-filha.INAL-PRIV EXIST 3REFL-avó ASS

'Tenho uma filha que vive com a avó (na mesma aldeia ou em outra região).'

(lit.: Privado de minha filha, mas ela existe com a avó dela.)

\author{
3c. ø-emsi-lï-mna $\quad w-a-i$ \\ 3POSS-filha.INAL-PRIV 1A3P-ser/estar-MOD \\ 'Não tenho filha.' (Nunca tive) (lit. Sou desprovida de filha.)
}

\footnotetext{
${ }^{6}$ Harmonia vocálica requerida: o sufixo -lu associa-se à sílaba final da palavra contendo a vogal /u/: tamu 'avô', itamulu 'o avô dele'.
} 
O índice pessoal da $1^{\mathrm{a}}$ ou da $2^{\mathrm{a}}$ pessoa aparece quando o predicado é marcado pelo existencial, man, e neste caso, como em $(3 \mathrm{c}, 4)$ o elemento possuído não está presente na situação de comunicação:

3c. j-emsi-lï-mna man

1POSS-filha.INAL-PRIV EXIST

'Não tenho filha.' (lit. existe privação de fillha presencial)

\section{4. ̈̈-munku-lu-mna man}

1POSS-filha.INAL-PRIV EXIST

'O meu filho não está aqui comigo.' (lit. Existe privação de meu filho, que não está atualmente aqui comigo, ou por não ter filho)

Acima, adiantei que o sufixo de inalienabilidade -lï aparece em uma construção afirmativa. Ele aparece junto ao termo de parentesco - pa 'neto/a' quando empregado em cantos antigos, em relatos míticos e também quando uma pessoa mais velha se dirige a uma mais nova, sem que ambasse conheçam (5b):

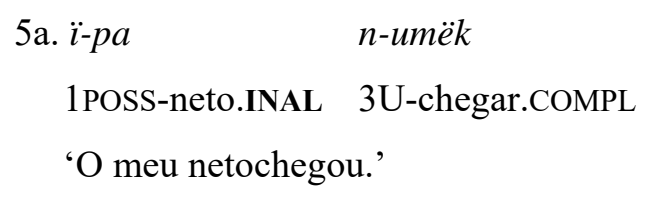

No processo derivacional marcado pelo privativo, -mna, o sufixo -lï é requerido:

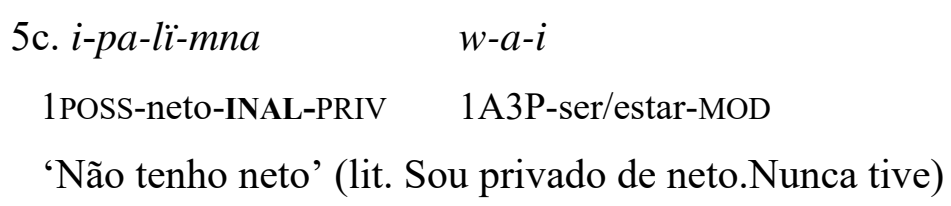

'O meu neto não está aqui' (lit. Sou privado de neto, por não estar aqui, ou por nunca tertido um.) 
Tamu 'avô' - na relação inalienável, ocorre uma harmonia vocálica entre a vogal final do termo possuído e vogal do sufixo de inalienabilidade. Se a vogal for a posterior -uo sufixo é representado por -lu (6), com as demais vogais é o sufixo -lïque se associa ao termo possuído:

6a. ï-tamu n-ente-ja-i

1POSS-avô.INAL 3U-tocar instrumento-INCOMPL-MOD

'(É o) meu avô está tocando.'

6b. i-tamu-lu-mna $\quad$ w-a-i, $\quad$ Aletani kwau man

1POSS-avô-INAL-PRIV 1A3P -ser/estar-MOD Litani LOC EXIST

'Estou sem o meu avô que está no Litani (Guiana Francesa).'

(lit. Sou privado de avô biológico [que faleceu, ou que vivelonge, na Guiana])

6c. İ-tamu-lu-mna man etutop pona n-ïtëm

1POSS-avô-INAL-PRIV EXIST reunião DIR 3U-ir.COMPL

'O meu avô não está (aqui). Ele foi a uma reunião.'

A relação inalienável ocorre com termos do corpo humano (7) e com termos inanimados (8):

7. kulasi ø-ele-lï-mna man

galinha 3POSS-fígado-INAL-PRIV EXIST

'O frango está sem o seu figado.' (lit. Existe privação de fígado do frango.)

O uso da canoa, kanawa,faz parte do cotidiano do grupo. Transporte indispensável para o deslocamento fluvial. O termo pode aparece sem nenhum:

8a. kanawa ihjan me-la

canoa nova EVOL-NEG

'A canoa não é nova.'

Em uma construção negativa marcada pelo privativo, -mna, o sufixo -lï, é agregado $(7,8 \mathrm{c}-\mathrm{d})$, mas este sufixo que expressa inalienabilidade nem sempre está presente em construções negativas (8a, 8e-f) ou construções afirmativas $(8 b)$ : 


$$
\begin{array}{clll}
\text { 8b. ï-kanawa ihjan } & \text { n-ëtakulika } & \text { tëpu pona } \\
\text { 1POSS-canoa nova } & \text { 3A3P-quebrar.COMPL } & \text { rocha } & \text { DIR }
\end{array}
$$

'A minha canoa nova danificou-se contra a rocha.'

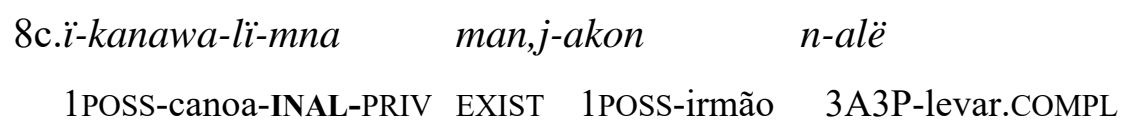

'Estou sem a minha canoa, o meu irmão a levou.'

\title{
8d. i-kanawa-lï-mna $\quad w-a-i$ \\ 3POSS-canoa-INAL-PRIV 1A3P-ser/estar-MOD
}

'Estou sem canoa.' (lit. estou privado de canoa [por nunca ter feito, nunca ter tido uma])

Em uma construção negativa tendo como predicado a cópula, o elemento possuído pode estar ou não indicializado. Quando não indicializado, a negação marcada pelo privativo (8e) remete ao fato de o "dono" estar sem a sua canoa que não se encontra no porto, talvez por ter afundado ou pelo rio tê-la levado (8e). A construção negativa em (8f) é reflexo de um uso arcaico, usado ainda hoje apenas por pessoas acima de 60 anos (tamusi omi 'palavra do velho'), empregando a negação -laque, no wayana contemporâneo, associa-se ao verbo e não ao nome:

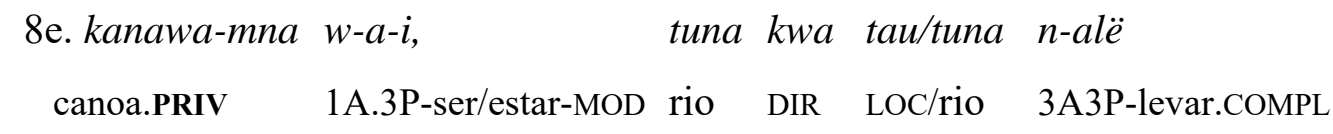

'Estou sem canoa. Ela está dentro do rio/O rio levou-a.'

\author{
8f. i-kanawa-la $\quad w-a-i$ \\ 3POSS-canoa.PRIV 1A3P-ser/estar-MOD \\ 'Não tenhocanoa.' (lit. sem a canoa, estou. Nunca tive uma)
}

Relação de alienabilidade - Em geral, objetos diversos são interpretados como alienáveis. Essa relação de alienabilidade é indicada na construção afirmativa pelo sufixo $-n\{u\}$. Na construção negativa ele aparece junto ao sufixo de privativo -mna $(9 \mathrm{c})$. A negação representada por -lanão requer o sufixo de alienabilidade (9d): 
9a. J-akupuita-n

1 POSS-remo-ALIEN

'(É o) meu remo.'

9b. ø-akupuita-nu-mna $\quad w-a-i, \quad$ kono $\quad n$-alë

3POSS-remo-ALIEN-PRIV 1A.3P-ser/estar-MODcunhado 3A3P-levar.COMPL

'Estou sem remo agora (por ter emprestado), o meu cunhado levou-o.'

9c. j-akupuita-nu-mna man

1POSS-remo-ALIEN-PRIV EXIST

'Estou sem o meu remo (que sumiu/não sei onde ele está).'

9d. ø-apukuita-la $\quad w-a-i$

3POSS-remo-NEG 1A.3P-ser/estar-MOD

'Não tenho remo (por não ter feito um).' (lit sem o remo dele estou.Ou seja, 'nunca tive remo.')

Com o negativo, malija 'faca', o sufixo -nu só aparece na construção de posse marcada pelo existencial, man. É agramatical o uso de -nu em que o predicado seja marcado pela copula (10c); e o negativo possuído não é indicializado como vimos nas construções acima. E construção negativa com o sufixo de negação -la não é admitida, *imalijala wai 'estou sem faca (nunca tive)'. Qual seria a razão dessa agramaticalidade? Talvez pelo fato de ser inadmitido uma pessoa nunca ter tido uma faca! Não há como uma pessoa não ter ou nunca ter tido uma faca, como se pode enunciar de um remo (9d). Se a pessoa não tiver remo, akupuita, ela usa um varejão, kula, para usar com a canoa, ou deixa a canoa deslizar, mas andar sem faca não é concebido. Se não é concebido uma pessoa não ter tal instrumento, por que ele é considerado alienável? Ao tentar fazer testes com o sufixo de inalienabilidade, os participantes das oficinas recusaram, um deles disse: a faca de outrora não era de metal! Talvez isso seja um argumento convincente. Eu por enquanto não me convenci, mas por enquanto deixo a resposta a essa questão ainda como incógnita. 
10a. ï-malija-n ihjan w-ekalë $\quad \ddot{e}-j a$

1POSS-faca-ALIEN nova 1A3P-dar.COMPL 2-DIR

'Eu dei para você a minha facanova.'

10b. Ï-malija-nu-mna man pakolo tau

3POSS-faca-ALIEN EXIST habitação LOC

'Estou sem a minha faca (aqui) emcasa.'

10c. malija-mna $w-a-i$, tuna $k w a-k \quad n$-ïtëmëm/n-ёmëm ${ }^{7}$ faca-PRIV 1A3P-ser/estar-MOD rio LOC-DIR 3U-cair.COMPL/3U-cair.COMPL 'Estou sem faca, ela caiu no rio.' (lit.Estou privado de faca que caiu no rio.) (*imalijanumna wai, pakolo tau - Estou sem faca dentro de casa.)

Vejamos um último exemplo. A tradição oral conta que dispor de uma habitação é recente, sobretudo depois que o grupo se sedentarizou. Outrora, dispunham de abrigos bem fechados para proteção contra insetos. Dormiam sob esteiras, tendo a casa da cozinha afastadadeste 'dormitório'. O dispor de espaço de dormir e de receber/trabalhar perto da cozinha parece ser umatradiçãoapalai. Em ambas as línguas, o sufixo de alienabilidade $-n\{u\}$ em wayana e -nyem apalai (i-tapyi-ny 3POSs-habitação-ALIEN) é requerido:

11a. Ï-pakolo-n ihjan

1POSS-habitação-ALIEN nova

'A minha habitação/casa é nova'.

11b.i-pakolo-nu-mna mïhen w-a-i

3POSS-habitação-ALIEN-PRIVque.pena 1A3P-ser/estar-MOD

'Infelizmente, não tenho casa onde morar.' (lit. estou infelizmente sem casa nesse lugar, não tenho onde ficar, aqui não tenho família.)

\footnotetext{
7 Para o verbo cair uma variação lexical -ïtëmëm (tïtëmëmhe) usado no Brasil e -ëmëm (tëmëmhe) empregado na Guiana Francesa.
} 
11c. ï-pakolo-nu-mna

man Jolokoma po, talë lëken i-hpe w-a-i

1POSS-habitação-ALIEN-PRIV EXIST Jolokoma LOC aqui ASS 3-ter 1A3Pser/estar-MOD

'Estou sem a casa em Jolokoma, só tenho aqui (na minha aldeia).'
11d. i-pakolo-la
$w-a-i$
3POSS-habitação-NEG 1A3P-ser/estar-MOD
'Nunca tive casa.' (em lugar algum)

Essas diferentes construções de posse mostram que além das diferentes relações semânticas mantidas entre o elemento possuidor e o elemento possuído, elas revelam, na construção negativa, marcada com o privativo -mna, uma relação espacial segundo a opção de predicado:

Com a cópula:

\begin{tabular}{|l|l|}
\hline «N-NEG-CÓPULA- » & Dispor do elemento possuído, mas não naquele momento \\
\hline «i.p-N-NEG-CÓPULA- » & Estar privado do elemento possuído. \\
\hline
\end{tabular}

Com o existencial:

\begin{tabular}{|l|l|}
\hline «N-NEGEXIST» & Estar privado do elemento possuído. \\
\hline «i.p-N-NEGEXIST» & Dispor do elemento possuído, mas não naquele momento. \\
\hline
\end{tabular}

Com a negação -la, o tipo de relação semântica entre os elementosnão existe.

\subsection{A alienabilidade dos instrumentos musicais, do mundo musical}

Em uma sociedade na qual a música é onipresente, espera-se que os instrumentos musicaissejam concebidos como inalienáveis. Ora, os wayanas interpretam esses instrumentos como a expressão material das entidades espirituais -jolok, remetendo a uma relação deles com os instrumentos e com o tocar à alienabilidade. O som emitido é a voz do jolok, o músico é ali apenas um mediador, ele não é agente da ação, mas sim um paciente ao tocar, ao dançar, ao cantar. Apesar de essa relação ser forte, a construção de posse tendo o elemento possuído um instrumento de sopro é marcada 
pelo sufixo de alienabilidade, $-n\{u\}$. Qual seria a interpretação do grupo para tal realidade gramatical? Ora, esse é um campo de domínio dos espíritos revela uma incompatibilidade com uma relação inalienável por serem mundos interligados, porém distintos.

12a. kïjapok $^{8}$ luwe-n $\quad$ ï-tamu $\quad$ ka-top
tucano flauta-ALIEN $\quad 1$ POSS-avô
'É a flauta do tucano do meu avô.'
(Isto é, trata-se da flauta que canta a voz da entidade-dono do tucano.)

12b. $\ddot{\text {-luwe-n }}$

1POSS-instrumento de sopro-ALIEN

'(É o) meu instrumento de sopro.'

A posse negativa segue os processos derivacionais dos demais exemplos vistos acima:
12c. i-luwe-nu-mna
$w-a-i$
3POSS- instrumento de sopro-ALIEN-PRIV
1A3P-ser/estar-MOD

'Eu não tenho instrumento.' (Disponho de um, mas no momento não o tenho, está emprestado.)

12d. ̈̈-luwe-nu-mna man

1POSS-flauta-ALIEN-PRIV EXIST

'Não tenho a menor ideia de onde esteja o meu instrumento de sopro.'

12e. i-luwe-la $\quad w-a-i$

3POSS- instrumento de sopro-ALIEN-PRIV 1A3P-ser/estar-MOD

'Não o tenho.' (Isto é, jamais tive um.)

O que ressalta dessas construções de posse é a onipresença do sufixo $-n\{u\}$ nas construções afirmativas marcando uma relação de alienabilidade. Morfema que geralmente aparece nas construções negativas, marcadas pelo privativo -mna. A morfologia não dá conta da relação de inerência e de inalienabilidade nas construções

\footnotetext{
${ }^{8} \mathrm{O}$ tucano é designado por kijapok no Brasil e kijapok na Guiana Francesa.
} 
afirmativas. $\mathrm{Na}$ verdade, a relação inerente não recebe nenhumamorfologia específica. A de inalienabilidade é caracterizada pelo sufixo -lï/lu que, no wayana moderno, sobrevive nas construções negativas expressando privação.

\subsection{A hierarquia da pessoa operando a relação actancial}

Os enunciados em (12) expõem a alienabilidade entre "X e oluwe", $\mathrm{O}$ instrumento de sopro (flauta, clarineta ou trompa)". O termo luwepode ser verbalizado: luweta- (tïluwetai). Ao serconjugado os índices pessoais da $1^{\mathrm{a}}$ e $2^{\mathrm{a}}$ pessoas do singular são os da série de prefixos pessoais da forma inativa:

\section{3.ї-luwete-i ; ̈̈-luwete-i}

(3A)1P-tocar.instrumento.INCOMPL-MOD;(3A)2P- tocar.instrumento.INCOMPL-MOD,

Eu toco instrumento de sopro./ Você toca instrumento de sopro.

(lit. ele me/te (faz) toca(r) o instrumento de sopro).

Essa forma inativa remete semanticamente ao "paciente", ou seja, àquele que toca não seria o músico/o instrumentalista. Seria a entidade-(espiritual) jolok que através do músico expressa a sua fala, o seu canto, a sua melodia. Pensando nesse conceito, pode-se entender que o instrumento musical pertence à entidade-(espiritual) jolok, que seria o seu dono, e não ao músico. Este seria entendido apenas como um intermediador da palavra-cantada ou palavra-musicalizada do jolok.

O caxinauá - Língua pano falada por aproximadamente 10000 indivíduos repartidos pela bacia dos rios Juruá-Purus, entre as fronteiras do Peru e do Brasil. Trabalho nessa região desde 1988 onde organizo oficinas de língua (praticamente anualmente) desde 2007.

Os enunciados ilustrados acima mostramuma conexão entre a morfossintaxe e a semântica ${ }^{9}$. Sob um outro registro linguístico, lexical, vejamos uma relação entre língua e cultura. O caxinauá propõe exemplos que lançam luz sobre a relação entre o homem e o meio. Nesta língua, objetos podem ser considerados animados, ou seja, o vegetal transformado não perde a propriedade 'animada' que lhe é atribuída culturalmente. Por

\footnotetext{
${ }^{9}$ Estudo realizado em colaboração com Mudu (Alberto Roque Toribio).
} 
exemplo, este grupo concebe a 'taboca' (Guadua paniculata Munro, Gramineae) como um elemento animado por sua agentividade; ela pode transformar-se no corpo de flecha que, por sua vez, conduz a sua ponta a matar. Pela personificação que lhe é atribuída, ela expressa estados como o de alegria, tristeza, descanso. Assim, caso passe um tempo sem caçar, a flecha pode apresentar um estado de tristeza, desamparo, tornando-se eufórica quando seu dono a pega para sair à caça. $\mathrm{O}$ mesmo se sucede com a espingarda que, devido à falta de cartucho, fica de lado, triste e faminta, na espera de que sua energia (isto é, os cartuchos) seja recarregada para voltar a comer/caçar. Tais aspectos culturais são expressos na língua, como veremos adiante.

\section{4 “Animacidade e Inanimacidade”, elementos adjacentes em caxinauá}

Quando falamos de 'objeto' ( $m a b u)$ em caxinauá devemos pensar em 'vegetal' manufaturado (miman). Tomemos como exemploa flecha (pia). Sua haste é fabricada com cana brava(tawa), suas pontas (pia debu) com pupunha brava (banim) e taquara (paka). Ao meu conhecimento não há $\operatorname{mitos}^{10}$ que trate da origem dos objetos manufaturados a partir do vegetal. A memória oral enuncia a existência no passado de cantos ao fabricarem as flechas, notadamente as pontas. No entanto, o que é vivo na expressão caxinauá é o sentimento de animacidade; em alguns casos, de personificação atribuída a esses objetos. Além da propriedade de personificação, alguns vegetais também podem ser classificados por gênero. À taboca atribui-se o campo do gênero masculino e ao algodão do feminino, por exemplo. Vamos nos restringir à "família da flecha” (pia kuin nabu).

Pia designa ocorpo da flecha, feito de cana brava (tawa), a pena (pei tetanea) e a ponta (pia debu). A flecha é classificada em quatro classes, estas caracterizando as pontas: pakafeita com taquara (paka), banim, bema kedeetxada, feitas com cana brava (banim). Todas dispõem de feitios diferentes: simples, com ranhuras, ou ainda com ponta farpada ${ }^{11}$.

\footnotetext{
${ }^{10}$ A memória oral diz haver cantos (pia pakadin) para a fabricação e uso de flechas, sem saber mais tais cantos, algunsdos participantes das oficinas arriscaram a cantarolar um pouco.

11 Atualmente usam prego para a fazer a ponta de flecha: lixam o instrumento de diferentes modelos. Usam também, espintana, xai, madeira bem durae pesada.
} 
A animacidade da flecha - O conjunto de quatro "flechas" apresenta um conceito de família: o esposo (bene), a sua esposa (ain) e seus dois filhos/descendentes (hatunbakebu), estes representados por "meninos"; nessa sociedade cinegética raras são as mulheres que caçam, este é um campo majoritariamente masculino.

A ponta $p a k a^{12}$ é considerada 'masculina', o mestre de todas, ela é fina (demesin $\left.{ }^{13}\right)$ e afiadíssima (kenua). Nela passava o curare (senpa).

A ponta tridente $t x a d a^{14}$ é a sua contrapartida feminina, hawen ain, 'sua esposa'. As outras duas pontas são os descendentes (hawen bakebu): banim é o bake ewa, o 'primogênito' e bema kede, é o hawen hakatxu, o 'segundo filho'. Cada uma delas exerceum papel diferente: Paka, o esposo, é usada para caça grande (yuinaka ewapa ${ }^{15}$ ) etxada, a esposa, para caça pequena (yuinaka pixta ${ }^{16}$ ). A ponta da paka, feita de taboca, outrora chamada de piapaepa 'ponta de flecha forte (tóxica), continhao anestesiante chamado curare (senpa). O caçador lançava-a primeiro (tsaka taea) para amortecer o animal e em seguida lançava uma ou mais flechas (namea) $)^{17}$. Se a paka pode ser lançada para um trajeto longo e retilíneo, perfurando o corpo do animal, o mesmo não ocorre com txada de ponta farpada que não vai nem muito alto, nem muito longe, além de requererespaço amplo para voar livremente; ela leva pena, peiya. Sua ponta pode ser deduas laterais (txadadabe kede) ou de três laterais (txada xextxa ${ }^{18}$ ) farpadas, quando feitas de pupunha brava (banim) ou de prego rosqueável (txada xextxa). Ela não entra muito no corpo da caça, mas segura as caças pequenas impedindo o movimento delas.

Nessa classe de flecha encontra-se a dututi chamada regionalmente de "biloto". Ela não tem ponta, seu objetivo é abater a ave ${ }^{19}$ evitando feri-la na pele e danificar as penas; mata pelo forte e rápido impacto. A banim apresenta diferentes pontas com farpas: uma ponta bestitxai kedecom farpas em apenas uma lateral, o rabo de arraia com

\footnotetext{
${ }^{12}$ Paka é uma taboca parecida com bambu sem espinho, a sua ponta é feita de taboca também.

${ }^{13}$ Palavra derivada: debu-mesi-n (ponta-fina-genitivo).

${ }^{14}$ Txada, suas pontas são comofarpas (kede) feitos com pupunha brava, banim.

${ }^{15}$ Anta, awa, queixada, yawa kuin, catitu, hunu yawa, veado, txaxu, cotia, madi.

${ }^{16}$ Coatipuru, kapa, suim, xipi, saracura, taku, bem-te-vi, kaya isa, nambu, xudi, nambuzinho, benkum. Mata também cutiara, tsanas, quando está dentro da cabana de caça, xubu.

${ }^{17}$ Aprática de lançar primeiro uma flecha para adormecer a caça grande e em seguida terminar de matá-la com outras flechas, aparece na narrativa de Kuin Dume Teneni que ao ir matar com a sua esposa, ele o KDT usava a lança, haxi, para o primeiro golpe e ela atrás vinha com a borduna, binu, para o golpe final. ${ }^{18}$ Com prego (mane txada) faz-se outras pontas: puntxa txada, xextxa txada, sakaya txada.

19 É usada para matar passarinhos como periquito, pitsu, beija-flor, pinu, maracanã, txaya, curiquinha, txede.
} 
dentículos, i hina kede, como se tivesse barbatanas de raia dos dois lados da seta (que seria a farpa do peixe). A seta kede bextxaapresenta farpas nos seus dois lados.Tem-se ainda a seta banim xenetan com uma ou duas farpas.A essa mesma ponta pode-se agregar um coquinho (pani hexe, hepe hexe) com um buraquinho amarrando no meio da haste. Esta flecha é chamada de banim betximati, ao ser lançando ela assobia (sudu-sudu iki) para que os macacosque estão escondidos saiam de seus "esconderijos" (nas árvores). Essas pontas chamadas banimsão usadas na flecha que se atira por primeiro (tsaka taea), se o animal continua vivo, serve-se de outras flechas para os demais tiros (namea). Elaé usada para atingir animais de pequeno porte, de terra (main anua ${ }^{20}$ ) e de ar (manan udia $\left.^{21}\right)$ que estão longe do caçador, exigindo desse um bom alvo (ninunpuntu watan). Essa flecha penetra fundoo corpo da caça (pida $w a a^{22}$ ), às vezes atravessando-o completamente (txankan waaou texun waa); ela faz o seu trajeto com bastante velocidade (bebinkidimaa). A ponta bema kede (farpa de sapopemba) é do tipo rosqueável com três laterais.

Vimos que um dos segredos da flecha é a sua ponta com uma diversidade de formas, conforme o tamanho da caça ou pesca. A pena, pei, é um elemento importante por auxiliar na estabilidade do seu trajeto. A txada não leva pena (txada pei uma) por ser pesado (xankama). As demais sim, dependendo do tipo de caça que o caçador quer atingir. Se a ponta for pesada a pena é grossa, banim xudu peiya, esta é usada para animais que se encontram perto da cabana de caça, $x u b u$, para caça de terra. Se a ponta for fina, a flecha é leve (xanka) para voar alto, neste caso chamam a pena para esse tipo de flecha de banim nunkupa peiya ou pia nunkupa, usada para caças do ar.A paka geralmente não leva pena, para animais da terra, ela tem a ponta longa e fina para voar longe. Leve aquela feita para matar macaco prego, isu, e guariba, du, para paka peiya. A bema kede que predomina caças do ar usa pena para ir o mais alto possível. A flecha, leve (xanka), é nunku peiya, ou seja, tem pena. Para a caça de terra, a ponta é larga, grande (хиdupa, ewapa) ela é pesada não precisa de velocidade pela presa estar

\footnotetext{
${ }^{20}$ Catitu, hunu yawa, queixada, yawa kuin, paca, anu, veado, txaxu.

${ }^{21}$ Coati, xixi, mutum, hasim, jacamim, nea, jacu, kebu e macacos como macaco preto, isu kuin, macaco vermelho, isu kudu, macaco prego, xinu, cairara, abu xinu, guariba, $d u$.

${ }^{22}$ Penetrar de tal forma que a ponta aponta pelo lado de dentro da pele do animal, expresso também por ukedi texun waa.
} 
próxima, caso tenha uma ponta leve ela leva pena (xudu peiya). O caxinauá ainda prendia a pena em formato espiral, hoje usa duas penas.

O caçar das flechas - O caxinauá usa dois verbos para matartsakai para animais de terra (main anua) e aki para animais do ar (manan udia). O primeiro verbo designa o 'caçar'/'matar' animais que estejam perto do caçador (txaima); ação realizada com paka, o esposo, e txada, a esposa, revelando experiência. O segundo verbo designa o 'caçar'/'matar' animais que estejam longe do caçador (txai), ação executada pelos descendentes que são jovens, expressando força.Ao lançar a flecha, dizem que esta faz ruídos reconhecidos assim: tsan aki quando lançada para um animal de terra que está próximo, o barulho é seco, como se tocasse forte; tsuis aki quando lançado para um animal que está longe, o ruído é agudo, como se tocasse de leve, kex aki é o barulho dito feito pela flecha paka, com um ruído grave. O quadro abaixo esquematiza a classe das flechas:

Quadro 1. Pia kuin xiadabu/Tipos de flechas

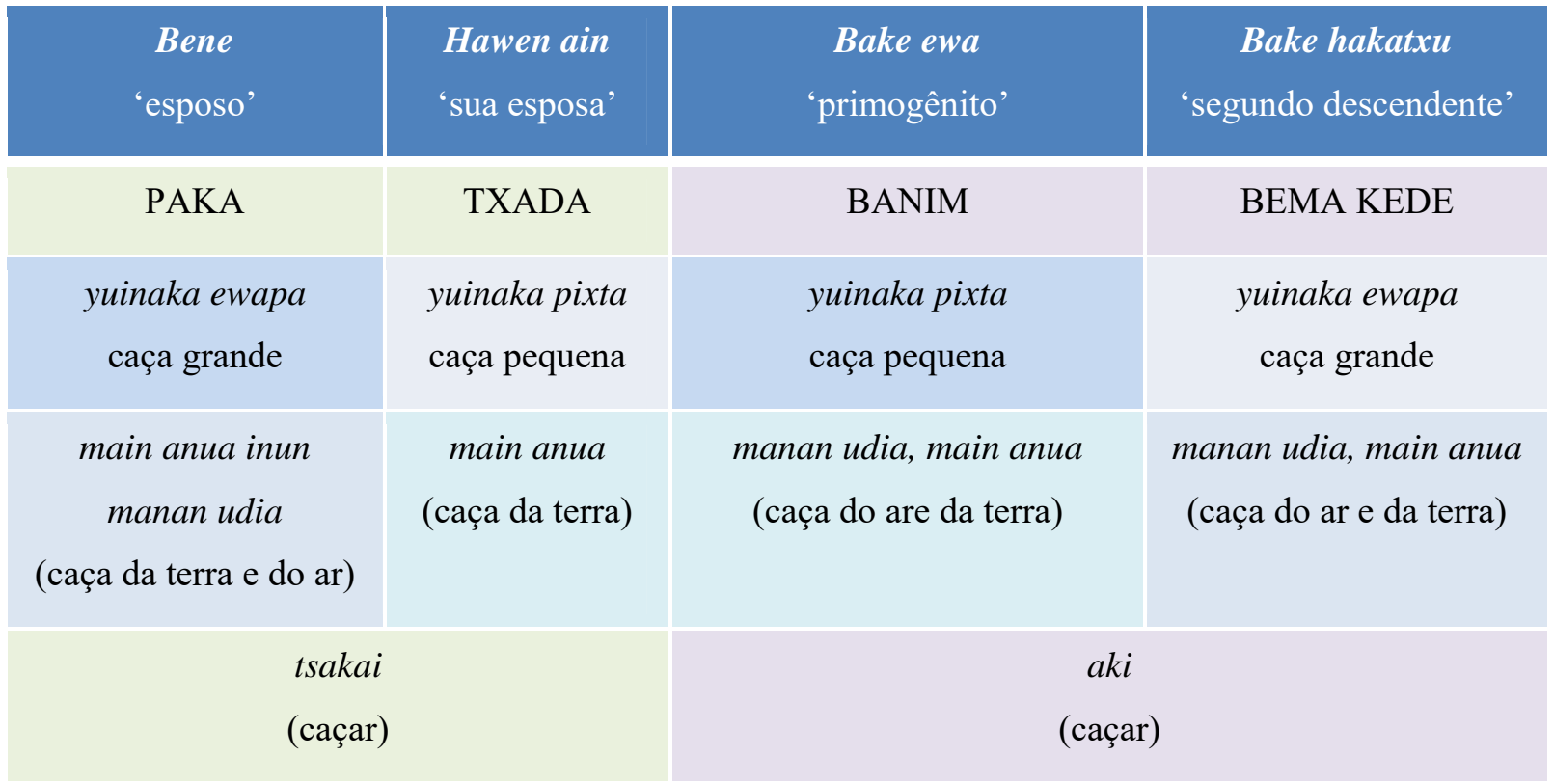

Pia kuin nabu. Este quadro esquematiza uma relação que revela uma simetria dos papéis pais-filhos, levando em conta a onomástica no interior da filiação, e uma relação espacial entre 'terra e ar'. Há um paralelo entre eles dando equilíbrio entre a caça grande e pequena: a caça do esposo/pai e do filho mais velho são expressos por tsakai, a da esposa/mãe e do segundo filho são enunciados por aki. Cada verbo tem a sua contrapartida de caça grande e pequena o que reparte as tarefas sociais e as de 
transmissão: o pai tem a responsabilidade da educação do primeiro filho que será o seu sucessor, sobretudo sendo filho de chefe:

Quadro 2. Relação de simetria dos papéis pais-filhos

\begin{tabular}{|l|l|c|c|}
\hline Tipo de flecha & Caça predominante & Espaço & Verbo caçar \\
\cline { 1 - 2 } paka 'esposo' & caça grande & terra & tsakai \\
\cline { 1 - 2 } txada'esposa' & caça pequena & \multirow{2}{*}{ ar } & \multirow{2}{*}{ aki } \\
\cline { 1 - 2 } banim 'primogênito' & caça pequena & \\
\hline bemakede 'segundo filho' & caça grande & \\
\hline
\end{tabular}

A relação pai-primogênito revela, por sua vez, uma relação onomástica, visto que o primogênito recebe, em princípio, o nome do avô paterno, conferindo-lhe, assim, o pertencimento a uma metade social. Neste caso, tem-se o seguinte conjunto:paka, caça grande, esposo-pai, e banim, com caça pequena, primogênito. No caso da mãe e seu segundo filho, a mãe txada seria o mestre da caça por ter a função de matar animais da terra. O segundo filho bema kede sempre recebe o nome da família de sua mãe, isto é, de um irmão da avó materna, pertencente à mesma metade social do pai de sua mãe, ou seja, de seu avô. Tem-se assim o conjunto: txada, esposa-mãe, caça pequena, e bema kede, filho menor, caça grande.

A animacidade da flecha, espingarda - A personificação da flecha é revelada no discurso caxinauá através de uma percepção 'familiar' que o dono, ibu, tem com ela, como evidenciam os enunciados abaixo. Na concepção caxinauá, o caçador não guarda a flecha no teto da casa: ele a conduz ao habitat onde ela vive/mora (hiwei). O gesto de pegá-la para levá-la para caçar não é visto como uma ação do caçador, mas sim um movimento inverso: é a flecha que desce (butui) de onde mora (bitxamei) para ir caçar, sendo ela, portanto, o agente de matar - ela procura a caça e a mata. Fica feliz por comer a carne que fica colada em sua ponta.

14a. Pia kuin hiwe anua bitxamea, butukaini kaidan, ni medan hikikainkin, yuinaka benabainmiski. Hanua detemiski, hawen xebuduwendan ${ }^{23}$, yuinaka mawaaya, hawen xebudu xetsekemiski. Nami xeustameadan, himin idumadan haskaidan benimai imiski yuinaka pidan. Haskatani.

\footnotetext{
${ }^{23} \mathrm{Xebudu}$ 'gume da ponta'.
} 
'A flecha mora enfiada no teto ${ }^{24}$; quando desce vai para o mato procurar caça. Daí mata com a sua ponta da flecha. Quando a caça está morrendo, o caçador tira a ponta que ficou encravada na carne ${ }^{25}$. A carne fica grudada na flecha, lambuzada de sangue, e com isso ela fica feliz por comer caça. É assim que acontece.'

A propriedade de personificação dada a este vegetal transformado é ainda expressa pelo sentimento que a flecha revela ter: 'o estado de felicidade, ao voltar para casa, exprime que a ação de matar e comer fora realizada'.

14b.Hui benimakidanmiski, hawen bitxati anu huidan. Hanua hikituxitan, datekede iki petan, hawen bitxati anu daka huindukunmiski.

'A flecha volta (da caça) contente para casa ${ }^{26}$. Logo na volta da caça, o caçador a enxuga, limpando (os restos de carne e do sangue). Assim, ela volta (limpa) para descansar em seu canto (sua casa).'

A propriedade cinegética das flechas é expressa pelos estados de felicidade e de tristeza decorrentes do fato de ter ou não a caça. O contentamento revela-se por poder comer a carne encravada em sua ponta, ao passo que a tristeza toma conta delas quando não são levadas para caçar. As flechas, então, permanecem deitadas em seu canto, fazendo manha:

15. Tsuan iyutima ixi iki, kaxamiski, dakadan hawen bitxati anudan.

'Quando não tem ninguém para levá-la caçar, a flecha faz manha ${ }^{27}$. Chora deitada no seucanto.'

A assimilação à personificação igualmente se revela ao comparar as pontas de flecha às categorias etárias dos humanos e aos seus estados de saúde:

16.Bena waayadan, hanua pia xeni isin tenei tekei, huni kuin mestebui tekei piadan.

Hanua bena bedundan.

\footnotetext{
${ }^{24}$ Bitxamea A flecha é guardada enfiada na palha do teto da casa.

${ }^{25}$ Xetseke A ponta solta do corpo.

${ }^{26}$ Bitxati 'lugar de guardar a flecha'.

${ }^{27}$ Ixi iki, pia ixi imis A flecha fica fazendo jeito de querer chorar.
} 
'Quando se faz novas flechas, as velhas ficam doentes, envelhecem e se quebram, ao passo que asnovas são moças.'

O dono da flecha conversa com ela, pois têm uma linguagem comum entre eles, chamado de mawamakin 'para imitar (a fala)'. O dono pode dizer à flecha: Kaneama ea axunxanwe 'Não erre o alvo, cace para mim!'

Esses enunciados ilustram que uma sociedade, como a do caxinauá, pode interpretar uma relação entre humanos e elementos da natureza transformados em objetos como um continuum, dentre de suas redes de sociabilidade. Vemos que a tipologia linguística traz informações como essas que também são de interesse para a etnologia, por revelarem de forma plausível a maneira como o homem percebe e concebe seu universo. O linguista descritivo deve prestar atenção a esse tipo de fenômeno "elementar", apreendendo socioculturalmente a representação simbólica muitas vezes traduzida na língua. Caso contrário, o trabalho descritivo resultará apenas parcial, reduzido a um tratamento do funcionamento formal e estrutural da língua sem as suas reais nuanças semânticas, sem as quais a língua estudada dificilmente é representada em sua real dinâmica discursiva. Vale lembrar que a semântica pode ser a parte mais espinhosa de se apreender em uma língua, sobretudo quando não há um conhecimento considerável desta última, pois adquirir o seu sentimento linguístico requer convivência e muita prática enunciativa. Uma pesquisa baseada em elucidação, questionário ou tradução de texto não é suficiente para adquirir tal sentimento e revelar as peripécias semânticas da língua. O trabalho de documentação de língua e cultura teria, em princípio, de levar em conta a semântica relacionada em todas as disciplinas linguísticas; todavia, devemos reconhecer que nem todos os linguistas têm condições de tal investimento, seja por questões logísticas, de formação acadêmica, por questões pessoais ou, ainda, porque a língua com a qual trabalha não é mais praticada no sentido lato por falta de interlocutores potenciais entre os interessados. Muitas vezes isto ocorre porque os velhos, que convivem juntos, não dispõem das condições necessárias em seu contexto social para praticar a língua de origem. Há um outro caso, mais grave, que é o de ser o 'único locutor da língua'! Uma língua não vive sem interlocutores potenciais. Nesse sentido, a África e a Amazônia apresentam uma situação emergencial na questão de documentação de línguas, visto que muitas delas se encontram em estado iminente 
de desaparecimento. A documentação das línguas não deve, portanto, servir apenas para arquivar dados linguísticos, como também para sensibilizar seus falantes, sobretudo jovens, da riqueza da identidade linguística e sociocultural de seus antepassados, do valor e das razões de mantê-la viva. Tarefa nem sempre evidente, sobretudo junto aos jovens. Por outro lado, na Amazônia, notadamente na sua porção brasileira, há um movimento que é chamado de "resgate cultural". É neste âmbito que apresentarei abaixo doispedidos de "documentação da língua", feitos pelos apalais, wayanas e caxinauás, e foi dessa experiência que coletei os dados etnolinguísticos, analizados acima.

\section{Programas de documentação de culturas e línguas indígenas}

A apresentação de experiências de oficina de língua evidencia o forte interesse que tal atividade suscita junto a jovens indígenas. Os diferentes trabalhos apresentados a seguir foram realizados sobretudo junto com professores bilíngues, com exceção da experiência wayana na Guiana Francesa.

O livro sem título - o caso aparai. A população global aparai aproxima-se da casa dos quatrocentos indivíduos espalhados pelo Suriname (rio Palumeu, alto do rio Tapanahoni), Guiana Francesa (rio Litani) e Brasil (rio Paru de Leste). Este último acolhe a maior parte do grupo. Apesar da baixa densidade populacional, a língua aparai falada no Brasil corre menor perigo de extinção nos próximos dez anos quando comparada aos países vizinhos. Ainda assim, com menos de quatro centenas de falantes, o grupo entra na faixa daqueles que têm sua cultura e língua bastante ameaçadas e corre o risco de, em breve, fazer parte dos 'grupos do passado', daqueles que existiram em tal região, que detinham tal conhecimento, tal saber-fazer etc.

Entre fevereiro e março de 2006, uma oficina de cultura e língua apalai ocorreu na aldeia Bona, na qual jovens interessados participaram, entre eles sete professores bilingues. O objetivo era trabalhar a língua a partir de dados etnográficos que os próprios jovens coletariam junto aos anciãos. Tomada a decisão coletiva pelos temas de interesse - migração, guerra e grupos de pertencimento, - uma questão veio à tona: “Como trabalhá-los? Como fazer as perguntas aos velhos, se já não tinham mais o hábito de perguntar nem mesmo o de escutar o que era contado pelos mais velhos?". Quatro tardes, no decorrer de uma semana inteira, foram dedicadas ao "treinamento", no 
qual os participantes acompanhavam-me a um bate-papo com um ancião. Desse batepapo temático, eu começava a conversa em português, com algumas intervenções em aparai, pedindo ao interlocutor para responder em sua língua. Em seguida cada participante intervinha. No dia seguinte pela manhã, eles me apresentavam um resumo da 'entrevista' escrita em aparai. Outro passo foi discutir esses resumos e de eles, por si, voltarem ao encontro dos anciãos de suas famílias ou não, para aprofundarem 'cada pesquisa conforme o tema'. Aproveitaram a oportunidade desse trabalho e pediram-me: "Você pode levar a gente para falar com o xamã!" A minha condição de pesquisadora e de ser conhecida pelo grupo me conferia certa liberdade de aproximação junto aos anciãos e notadamente do(s) xamã(s). Fomos todos à aldeia do grande xamã que não entendeu o nosso interesse repentino e coletivo em conversar sobre assuntos diversos. Primeiro ele me deu uma chamada por ter chegado em sua aldeia daquela forma, em seguida aceitou falar apenas em wayana com todos os presentes. A conversa tomou não apenas uma tarde inteira como fomos convidados a compartilhar a refeição da noite com o xamã. Recepção que deixou o grupo bastante surpreso, mostrando o quanto falar da cultura agrada aos. A gravação foi proibida, exceto para o colaborador wayana da Guiana Francesa que lá estava conosco. Os participantes disseram que aprenderam bastante, mas ninguém ousou a escrever um texto - um resumo que fosse - sobre ao menos um dos assuntos discutidos com a personalidade da área.

Após assimilarem a metodologia e o ritmo de trabalho, propuseram-me um 'calendário': o trabalho coletivo realizar-se-ia pela manhã e o de entrevistas à tarde. $\mathrm{O}$ dia de quarta-feira e a manhã de quinta-feira seriam dedicados ao roçado, à pesca/caça e à ressaca do caxiri, que durante as oficinas seria consumido às quartas-feiras e aos fins de semana. Pela manhã, cada um dos participantes apresentava o que havia coletado na véspera e juntos trocavam idéias sobre as informações obtidas pelo colega. Em caso de dúvida, chamavam um ancião para retomar a questão, expondo-a à classe. Assim compuseram mapas da migração de seus antepassados, descobriram que estes faziam troféus da cabeça de seus inimigos e que fabricavam flechas sarbacanas médias, dados não conhecidos da literatura antropológica desta área. As diferentes informações eram retrabalhadas por tema e uma redação em comum era elaborada. Esta última era corrigida na lousa a fim de se estudar a língua, discutindo regras de gramática. Decidiram, então, elaborar um livro de história monolíngue com as informações que 
coletaram compondo diferentes textos. Surgiu um problema: o título. Nenhum dos participantes quis propor um portratar-se de informações provenientes dos conhecimentos dos mais velhos. Eles, jovens, não se sentiam aptos a nomear um livro. Precisariam reunir todos os velhos da região - inclusive aqueles com quem não haviam trabalhado, expor otrabalho e consultar todos sobre um título para a obra. Fora da área preparei uma pré-maquete e lhes enviei para terem como material de difusão e discussão com os velhos. Três anos depois, recebi informações de que ainda estão pensando a respeito, e ainda continuam pensando sem chegar a consenso comum!

Nesse trabalho, que no início os aparais "confessaram" ter aceito departicipar pelo pagamento, deram o máximo de si, visto que a experiência constituiu um aprendizado da própria história deles. Um dos participantes expressou: "Não tenho mais tamu (avô/s) e nem pai (zumy '(o) meu pai biológico', japohpo '(o) meu pai classificatório, ou seja (o) irmão do (meu) pai'). Não posso questionar ninguém." Respondi ser uma grande pena, pois estava em uma família de gente que sabia muito. Alguns dias mais tarde, ele disse: "Converso com a minha esposa que à noite entrevista o pai dela e depois em casa ela me conta o que o sogrodisse. E daí eu escrevo." Ao final da oficina, este mesmo rapaz disse que graças a esse trabalho coletivo ele pôde, de forma indireta, ter acesso a informações de sua própria história que, pelo fato ser órfão, não tinha.

Dessa oficina, cujo relatório foi escolhido pela UNESCO para representar o Brasil no âmbito do Registre de bonnes pratiques de préservation des langues, o ponto culminante foi o interesse dos participantes em obter novas informações sobre o próprio passado, o próprio saber, seguido por discussões em língua aparai e também sobre a língua.Tal projeto mostrou que um motor potente pode dar partida a qualquer momento quando um tema sensível desperta a curiosidade dos membros de um grupo sobre seu próprio passado, ou, ainda, sobre o seu próprio campo de saber e do saber-fazer.

O livro de duas páginas - o exemplo wayanana Guiana Francesa. O primeiro trabalho voltado à preservação cultural partiu de um jovem wayana, que em 2003 me disse ter feito algumas anotações de dois mitos contados por seu pai, os quais gostaria de deixar registrados "por escrito" para seus descendentes. Essas ideias estavam redigidas em duas folhas de caderno. Segundo ele, a geração mais nova, na qual ele se incluía, não se interessava mais pelas narrativas. Uma delas conta a gênese do 
maluwana, um disco de madeira sobre o qual figuram seres aquáticos e larvas monstruosas. Tal disco é colocado no alto do teto da casa redonda coletiva, o tukusipan, situado no centro da aldeia. A partir da ideia desse jovem wayana, elaboramos um projeto de livro bilingüe no qual apresentaríamos os aparais e os wayanas, seus mitos e uma análise sobre a mudança da relação que os wayanas mantinham com esse disco de madeira no passado e que mantêm no presente.

Antigamente o referido disco era fabricado longe dos olhares dos demais, que descobriam a beleza da arte do artesão somente no dia de colocá-lo no teto do tukusipan. Sua fabricação, além de ser exclusiva do campo masculino, envolvia restrições: somente homens adultos podiam fabricá-lo; a um homem cuja mulher estivesse grávida estava vetada a participação, sob o risco de causar má-formação do feto. Colocado no teto do tukusipan, mulheres grávidas não deveriam admirá-lo, pois os seres lá pintados poderiam penetrar no ventre, causando doenças. Na atualidade, um forte comércio gira em torno desse disco, levando jovens a quebrar o tabu ao constatar que sua fabricação poderia gerar-lhes fonte de renda. Em alguns casos, até mesmo mulheres fabricam-no. No entanto, se, por um lado, o tabu foi quebrado, de outro o grupo não aprecia a pilhagem que os 'Brancos' fazem dessa arte. É comum ver em Caiena, cangas, bandejas, fruteiras, bancos de bares pintados com os motivos do maluwana. Mataliwa chama a atenção à questão do desrespeito à propriedade intelectual do grupo, pois ocidentais estão comercializando algo que não pertence a seus antepassados e que tampouco conhecem sua origem. Com a publicação de Kaptëlo, em 2007, uma discussão maior tomou conta do grupo na Guiana, e alguns membros procuraram juristas a fim de encontrar uma solução legal para a proteção desse saber. A partir desse trabalho, um livro com o resumo do mito foi elaborado com uma dúzia dos motivos gráficos dedicados à coloração. Destinado às crianças de 4 à 6 anos, mas todas as idades usam-no, sobretudo os mais velhos!

O programa DoBeS nos caxinauás - Alguns membros do grupo foram precursores na demanda da documentação para que eles próprios pudessem "reaver" o material etnográfico coletado anteriormente por diferentes pesquisadores e viajantes. Por quê exatamente?

O processo de contato é um forte veiculador de mudanças. O caso caxinauá, como de tantos outros grupos amazônicos que enfrentaram a exploração sem limites da 
borracha, da castanha, da madeira, do minério, das obras para o dito desenvolvimento, como foi a Transamazônia, é enriquecedor do ponto de vista da resistência pela sobrevivência de um grupo em situação de contato contrariado.Durante três quartos do século XX, os caxinauás foram conhecidos "como índios seringueiros" (AQUINO, 1977; AQUINO; IGLESIAS, 1994; TASTEVIN,1925), em virtude de sua inserção no sistema da exploração da borracha. Disto resultaram consequências drásticas tanto do ponto de vista psicológico (dizimação epidêmica, estupro, trabalho forçado) quanto sociocultural e linguístico: suas comunidades tornaram-se o centro da fazenda-grande ou barracão, como foram denominadas no Acre, sua estrutura sociocultural foi alterada e a língua local passou a ter contato com a língua do patrão, ou seja, o português.Algumas décadas após os primeiros contatos, uma porção do grupo que vivia no alto Envira (Brasil) entrou em conflito com um patrão e se refugiou no interior das terras, no alto Curanja (Peru). Parte do grupo que ficou no lado peruano passou cerca de trinta anos longe do contato direto com membros da sociedade nacional. Esse curto período de separação do grupo é suficiente para mostrar as consequências do contato permanente entre grupos distintos, ou seja, desta parcela dos caxinauás em contato com outros grupos indígenas que não são os mesmos que ficaram e que estão em contato com os caxinauás do Brasil.

A transmissão do conhecimento opera de forma diversa de um lado e do outro da fronteira entre o Brasil e o Peru, onde eles se localizam. No lado brasileiro, resultou-se uma miscigenação cultural e linguística ainda operante, mesmo após a partida dos seringalistas. A simbiose atinge até mesmo cantos tradicionais como osdo ayahuasca (nixi pae). No lado peruano os caxinauás foram privados de realizar plenamente suas práticas culturais em virtude da onipresença missionária fundamentalista por mais de vinte anos. Tal privação persiste com a formação missionária de jovens caxinauás.Disto resulta que no Brasil o grupo expressa sua tradição ainda que uma boa parte dela, sobretudo no que concerne os rituais (cantos, danças e seu simbolismo), conhece uma profunda transformação no tempo. No Peru, ao contrário, tais rituais são conhecidos quase coletivamente, porém não são mais realizados por não compartilharem com os interesses missionários. Uma certa nostalgia é expressa por anciãos e jovens que gostariam de participar dos rituais que não conhecem. Todavia, representar o que lhes 
foi durante anos dito ser 'proibido'28 parece irreal; eles se lamentam, então, passivamente. Os caxinauás no lado brasileiro, por sua vez, procuram retomar essa tradição que lhes pertence, chamando tal processo de "resgate cultural".

Separados por geopolíticas diferentes e sem condições econômicas para realizar viagens de longa distância, tal como costumavam fazer antigamente, os dois grupos caxinauás não possuem um contato assíduo entre si. Descendentes do grupo peruano desceram o rio Purus em direção ao lado brasileiro nos anos setenta, onde, junto aos parentes da bacia do Juruá que trabalhavam no seringal Fronteira, passaram a ocupar o médio Purus. Desde então a migração caxinauá do Peru para o Brasil não cessou. Podese dizer que é nessa faixa do rio que os rituais passaram a se realizar (cf. LAGROU, 2007).

\section{O pesquisador e a documentação}

Desde 1994 efetuo pesquisas de campo junto aos caxinauás no Peru. Entre 1989 e 2014, realizei diferentes campos junto ao grupo no lado brasileiro. Em 2003, Joaquim de Paulo Lima Kaxinawa escreveu-me solicitando apoio para trabalhar com professores caxinauás, membros da OPIAC (Organização dos Professores Indígenas do Acre). Eles queriam uma colaboração estreita entre o pesquisador e o grupo. O que queria dizer com isso? Na época, Joaquim Maná cursava o Terceiro grau da Universidade Indígena do Mato Grosso (UNEMAT) e tivera acesso a alguns artigos sobre a descrição de sua língua. De sua perspectiva, entender o funcionamento da língua ajudaria a todos os professores caxinauás a:

- descrever os cantos, notadamente a parte não verbal;

- discutir as letras do alfabeto. Este apresentava algumas letras diferentes entre o adotadono Peru e o no Brasil;

- entender o estudo de um linguista in situ e a finalidade de seu trabalho;

- reaver o material linguístico e etnográfico até então coletado por diferentes pesquisadores;

\footnotetext{
${ }^{28}$ Proibição de realização e de práticas socioculturais por missionários notadamente protestantes do SIL assim como da Missão Suíça do Km15 em Pucallpa, Ucayali, Peru.
} 
- dispor de ferramentas linguísticas e etnológicas para uma colaboração mais eficaz no trabalho entre o pesquisador e a comunidade, tendo uma troca de conhecimentos mais equilibrada entre as duas partes.

Foi nesse âmbito que apresentei ao programa $\mathrm{DoBeS}$, que se realizou o projeto de documentação de língua e cultura em perigo de extinção, intitulado "Animacidade e mitologia em Huni kuin (caxinauá): um estudo da categorização linguística e cognitiva em uma língua Pano" (Animacy and mythology in Huni Kuin (Cashinahua): a study of linguistic and cognitive categorization in a Panoan language ${ }^{29}$. $\mathrm{O}$ projeto ocorreu de 2006 a 2011. Já em maio de 2006, realizamos a primeira oficina de língua e cultura na aldeia do Joaquim Maná; 26 professores e agentes agro-florestais caxinauás participaram.

Uma das primeiras preocupações apresentadas foi como anotar os cantos. Todavia, a preocupação não se restringia à parte verbal, mas também à não verbal, a saber, aquela comumente referida a uma onomatopéia ou simplesmente não anotada. Os caxinauás julgavam importante anotar os «he he he » ou «uhm, uhmm» de seus cantos. Com isso sugerimos fazer uma iniciação da língua por meio do sistema fonético e fonológico do caxinauá, o que permitiu ao grupo:

- entender como os segmentos fônicos se realizam. Viram, talvez pela primeira vez, o que é um sistema articulatório, tendo as cordas vocais e a língua como elementos primordiais da função articulatória;

- reconhecer o sistema fonológico e sua função distintiva;

- abordar esses dois temas de forma bilíngue, na qual a discussão passou por uma metalinguagem, permitindo ao grupo falar tecnicamente de sua língua na língua vernacular;

- introduzi-los à morfossintaxe do caxinauá, levantando alguns debates sobre como “melhor” falar ou "melhor" examinar a língua. O estudo de certos aspectos da língua gerou algumas discussões animadas, visto que alguns participantes não estavam de acordo com a aceitabilidade da expressão em discussão. Este tipo de discussão talvez

\footnotetext{
${ }^{29}$ Bernard Comrie, linguista (MPI-Leipzig) foi o coordenador geral; Philippe Erikson (LESC-CNRS, Universidade de Paris X), coordenador em antropologia; Eliane Camargo (LESC-CNRS), coordenadora em etnolinguística; Sabine Reiter (linguista, MPI-Leipzig), e dois pesquisadores-estudantes Ana Yano (doutoranda em antropologia-USP) e Hanna Thiele (estudante em tipologia linguística - MPI-EVA, Leipzig).
} 
tenha sido o ápice da oficina, pois os caxinauás se deram conta de que podem discorrer sobre questões da língua quando se tem os instrumentos linguísticos necessários para isso.

Ainda durante essa oficina, dois jovens professores, um do rio Tarauacá e outro do rio Humaitá, pediram-nos para receber uma formação em linguística na qual pudessem entender o funcionamento de sua língua e, assim, colaborar com as pesquisas em linguística sobre o caxinauá. Uma primeira fase desse trabalho de formação ocorreu em agosto de 2008 na Unicamp, durante uma oficina de documentação. Em seguida, em uma comparação entre a grafia caxinauá aplicada no Brasil e aquela aplicada no Peru, os participantes deram-se conta do sistema econômico empregado pelo lado peruano. Este último segue o sistema fonológico. Ficamos de retomar essa discussão a fim de unificar a grafia, com a qual os professores no lado peruano estariam de acordo. $\mathrm{O}$ mesmo, no entanto, não ocorre no lado brasileiro que, apesar da oficina, esbarra na dificuldade de entender o significado de 'unificação'. Estes querem elaborar em equipe um dicionário bilíngue, porém ainda estamos, por ora, em discussão sobre qual grafia utilizar. Tal discussão, sobretudo, no lado brasileiro, esbarra em dificuldades para chegar a um consenso. Deve-se lembrar aqui que a "fixação da grafia para muitos grupos indígenas" tornou-se uma questão política no Brasil e seus usuários têm certa dificuldade em separar a questão político-identitária da questão real da língua. Nossa posição, enquanto linguistas, é de não entrar na discussão. Vamos continuar a oferecer as ferramentas linguísticas necessárias para o entendimento do signo, das regras de escrita, do sistema fonológico da língua, do que seria um sistema de escrita econômico que possa facilitar a aquisição da escrita e da leitura para as crianças. Optamos por este tipo de debate focado na aplicabilidade e na praticidade da escrita, evitando, portanto, a questão política da escrita como identidade.

No que tange à cultura, de forma coletiva, a solicitação caxinauá era uma só: queremos reaver os dados etnográficos coletados por pesquisadores no passado, sobretudo ter acesso ao material registrado em áudio e vídeo coletado junto aos «parentes » do Peru. Os caxinauás no Peru são considerados, pelos caxinauás situados no Brasil, como mais "tradicionais" pelas razões expostas acima.

Oficina de língua e cultura nos caxinauás no Peru - No Peru, desde 2006, oficinas de língua e de cultura são organizadas anualmente tendo como objetivo 
apreender o funcionamento da língua caxinauá. Para isso, uma metalinguagem linguística é usada, o que permitiu a elaboração de um manual de linguística em língua caxinauá. Para abordar o sistema fonológico; estudaram fonética articulatória a fim de compreender os pontos de articulação e os modos de articulação; regras de realização, a estrutura silábica já foram estudados. $\mathrm{O}$ estudo desta última pelos participantes que discutindo em caxinauá permitiu apreender todo um fenômeno de harmonia vocálica emfronteira morfêmica, não encontrada até lá. $\mathrm{O}$ estudo de fusão (vocálica, consonântica e silábica, assim como processos de nasalização) está em curso de andamento. Esta primeira fase de estudo da língua na língua é primordial para o estabelecimento de regras de ortografia, sobretudo sobre como anotar e interpretar as fusões e a nasalização inerentes do sistema linguístico do caxinauá. Além deste manual de linguística em língua caxinauá, durante essas oficinas a equipa organizou dois livros sobre a História do grupo. Um deles é trilingue caxinauá-português-espanhol (A História dos caxinauás por eles mesmos), o outro é bilingue caxinauá-espanhol ( $\mathrm{La}$ cultura de los cashinahuas). O primeiro é fruto de transcrições de relatos realizados durante o projeto DoBeS. Os transcritores selecionaram textos sobre a vida de antigamente por acharem interessante para o uso com crianças, pois eles mesmos com trinta anos desconheciam muitos dos fatos ali contados. $\mathrm{O}$ segundo atente a um pedido de um professor caxinauá que em 2007 remeteu-me anotações que fezsobre histórias contadas por sua avó. Editei as notas em versão Word, e o professou constituiu uma equipe de sete caxinauás para revisar os textos. Ao relê-los, a equipe expressou o desejo de inserir outros textos sobre ritos com cantos e danças, trabalho que vínhamos realizando desde 2010; agregou-se também um terceiro capítulo sobre memórias de vida. Esses dois estudos são frutos de um trabalho de reflexão sobre a língua e a cultura e seu registro por escrito seguindo regras ortográficas e um alfabeto uniforme, econômico, baseado nos fonemas da língua. A leitura não será fácil para o caxinauá não habituado, professores estão sendo treinados para que a escrita siga regras de ortografia relevantes do estudo da gramática (ver abaixo sobre a uniformização do alfabeto caxinauá no Peru). Esse mesmo grupo participou das "oficinas do Capistrano de Abreu" e durante cinco anos revisaram o livro bilíngue caxinauá-português deste historiador que o publicou em 1914. 
DoBeS: documentação da cultura e da língua caxinauá- A equipe DoBeS/Caxinauá vem trabalhando nesse sentido. Voltamos ao Peru seisanos seguidos, de 2006 a 2011. Coletou-se (em áudio e vídeo) um volume importante de material etnográficopara transcrever e traduzir em português e em espanhol. Estamos formando alguns membros para lidar com o material de vídeo e dispondo de computadores para utilizar o programa de transcrição ELAN que o MPI-Nijmegen elaborou especialmente para o trabalho de transcrição, tradução, comentários, segmentação morfológica, convertendo, em seguida, todo o material para o toolbox.

O conjunto desse material linguístico e etnológico está arquivado no MPINijmegen. O acesso é livre a todo caxinauá, com algumas poucas restrições internas; a restrição será maior para o uso exterior, com normas em acordo com a comunidade. A restrição interna provém de alguns velhos caxinauás que estão dispostos a colaborar conosco, porém não admitem que "sua fala, seu conhecimento" saia do âmbito de sua família próxima. Para a restrição externa, há determinados temas, como o xamanismo e o endocanibalismo, que os próprios caxinauás não desejam torná-los públicos. Eles emitirão autorização para o acesso externo a certos dados. Outros dados serão de livre acesso e divulgados pelo site da DoBeS, no portal caxinauá.

Este projeto de seisanos não significa, todavia, que o trabalho tenha sidoconcluído nesse período. O trabalho da equipe será de dar continuidade e apoio ao grupo, trabalhando em colaboração na formação de jovens sobre instrumentos linguísticos e etnológicos in loco ou na cidade com uma logística apropriada.

\section{Oficina de documentação de culturas e línguas indígenas}

De 25 a 30 de agosto de 2008, Angel Corbera (Unicamp), Bruna Franchetto (MN-UFRJ) e Eliane Camargo (EREA [LESC-CNRS]) organizaram no IEL-Unicamp uma oficina de documentação de culturas e línguas indígenas. Tal evento contou com a participação de vinte professores indígenas dos programas DoBeS-Brasil (aweti, trumai, kuikuro e caxinauá), DoBeS-Chaco argentino (moscovi, tapiete), e SOAS-Chaco argentino (pilaga), bem como de grupos estudados por acadêmicos do IEL-Unicamp ${ }^{30}$ :

\footnotetext{
${ }^{30}$ Infelizmente não foi possível contar com a presença dos cadivéus.
} 
kaingang, kamaiurá e mehinaku, participantes-especialistas dos programas DoBeS, acadêmicos do IEL-Unicamp, convidados como Pedro Cesarino, professor do Departamento de História da Arte da UNIFESP, e José Carlos Levinho, diretor do Museu do Índio-RJ. Durante os cinco dias de trabalho houve conferências sobre um tema específico seguido de oficinas com membros de cada grupo. Os temas proferidos foram: Diversidade linguística (B. Comrie, MPI-Leipzig), Estudo sobre fonética e fonologia (F. Sândalo, IEL), Sistema de representação da escrita e sua unificação (E. Camargo, EREA [LESC-CNRS], Tekuremai, S. Drude, MPG), Artes verbais: tradução e escrita (P. Cesarino, USP, B. Franchetto, MN-UFRJ), Documentação de culturas e línguas no âmbito do Patrimônio cultural (J. Levinho, Museu do Índio), Documentação de culturas e línguas indígenas como a elaboração de dicionários eletrônicos, a partir de programas como LEXUS e ELAN, desenvolvidos pelo MPI-Nijmegen (Holanda): Aweti (S. Drude), Kuikuro (Br. Franchetto) e a experiência da documentação da língua e cultura kuikuro no projeto DoBeS (B. Franchetto, Mutuá Mehinaku Kuikuro e Takumã Kuikuro). A oficina contou, ainda, com a colaboração de Sabine Reiter, Ana Yano e dos alunos do PPG-IEL.

A interdisciplinaridade - antropologia e linguística - chamou a atenção dos professores indígenas por tratarem de aspectos específicos da língua, como a 'escrita', em conexão com as artes verbais, ritos, cantos e mitos. A confluência de uma diversidade étnica e linguística possibilitou aos membros de diferentes grupos uma rica troca de conhecimento, com vídeos e $\mathrm{k} 7$.

Durante a oficina sobre a língua caxinauá (fonologia e gramática), realizada no Peru em setembro de 2010, sob o tema "uma língua, um alfabeto", o grupo e professores bilíngües optaram por um alfabeto seguindo o sistema fonológico da língua. Isto proporcionou uma economia e simplicidade de letras (quatro vogais e catorze consoantes) para os segmentos fônicos complexos, permitindo uma aprendizagem mais fácil do alfabeto e, consequentemente, da leitura. (Organizado pelo Ministério de Educação do Peru e TEKUREMAI ${ }^{31}$, com apoio logístico da Unidad de Gestión Educativa Local de Purus). Um ano após, o alfabeto composto de quatro vogais (a, e, i, u) e quatorze consoantes (b, d, h, k, m, n, p, s, x, t, ts, tx, w) foi oficializado pelo Ministério de Educação do Peru, por publicação no Jornal Oficial. Observem que o alfabeto

${ }^{31}$ Associação desativada em 2012. 
apresenta uma sequência diferente. A letra "x" aparece após a letra "s". Isto mantém um paralelo com a sequência das letras compostas "ts" e "tx", seguindo uma certa lógica de regras linguisticamente refletidas para a língua, agora também escrita.

Essas diferentes iniciativas realizadas em colaboração com membros de diferentes grupos indígenas mostram que há, sim, a possibilidade de sensibilizar jovens indígenas sobre o valor de suas culturas e línguas e que isso não é nada incompatível com viver e crescer em convívio com ao menos dois sistemas socioculturais opostos. É necessário entender o funcionamento do sistema nacional, tanto sociocultural quanto econômico, o que lhes derá abertura ao entendimento de que não é abandonando o sistema de vida dos antepassados que terão mais respaldo na sociedade nacional.

É inevitável a realidade vivenciada por alguns grupos indígenas que se encontram em uma situação sociocultural e linguística precária, não conseguindo encontrar soluções para uma volta ${ }^{32}$ ou recuperação de seu saber. Há, contudo, grupos numericamente pequenos como os aparais com quem um trabalho de conscientização do valor de seus conhecimentos pode despertar interesse da nova geração. Valorizando o que é deles, podem vir a encontrar uma forma de reencontrar sua dignidade identitária social, cultural e linguística. E, nesse sentido, programas de documentação sob forma de oficinas, de formação de jovens em disciplinas diversas nas quais eles possam apreender o saber do Outro para aplicar no seu sistema pode vir a ser uma das formas de remediar a situação. Isto é, formar jovens a manejar por exemplo uma câmera vídeo para gravar as atividades mais diversas de sua aldeia, e computadores e programas de transcriçãotradução, seria uma forma desses jovens participar da consolidação e a preservação de seu saber.

\section{REFERÊNCIAS}

AQUINO, Terri. Índios Kaxinawá: de seringueiro caboclo a peão acreano. Dissertação (Mestrado em Antropologia Social), Universidade de Brasília, Brasília, 1977.

AQUINO, Terri V.; IGLESIAS, Marcelo P. Kaxinawá do rio Jordão. História, território, economia e desenvolvimento sustentado. Rio Branco: Comissão Pró-Índio (AC), 1994.

\footnotetext{
${ }^{32} \mathrm{O}$ sentido de 'volta' aqui é principalmente no que tange o 'saber' e o 'saber-fazer'.
} 
CAMARGO, Eliane (Org.). João Capistrano deAbreu - Rã-txa hu-ni ku-ĩ, a língua dos caxinauás. Obra revisitada. São Paulo: Editora da Unicamp, 2017.

CAMARGO, Eliane; VILLAR, Diego (Orgs). Huni kuin hiwepaunibuki, A história dos caxinauás por eles mesmos; La historia de los cashinahuas por ellos mismos. São Paulo: Editora do SESCSP, 2014.

CAMARGO, Eliane; KULIJAMAN, Mataliwa. Histoire et langue: un défi à relever pour les Apalais. Relatório aprovado pelo Register of good practices in language preservation-Unesco, Paris: UNESCO, 2006.

CAMARGO, Eliane; REITER, Sabine. Arte da oralidade, arte de sua transmissão: contar mitos em caxinauá (Pano). In FERREIRA, M. (ed.), Tradições orais de línguas indígenas. Campinas: Pontes Editores, 2013, p. 13-40.

GIPPERT, Jost; HIMMELMANN, Nikolaus P.; MOSEL, Ulrike (eds.). Essentials of Language Documentation. Berlin/ New York: Mouton de Gruyter, 2006.

GRINEVALD, Collette. Speakers and documentation of endangered languages. InAUSTIN, Peter (ed.), Language Description and Documentation, Vol. 1. (Endangered Languages Project). London: School of Oriental and African Studies, 2003, p. 52-72.

KULIJAMAN, Mataliwa; CAMARGO, Eliane.Kaptëlo: L'origine du ciel de case et du roseau à flèche chez les Wayana (Guyanes). Paris/Cayenne: GADEPAM-CTHS, 2007, 124 p. ilustrado.

LAGROU, Els. A fluidez da forma: arte, alteridade, e agência em uma sociedade amazônica (Kaxinawa, Acre). Rio de Janeiro: Topbooks, 2007.

POTTIER, Bernard. L'ethnolinguistique amérindienne. Amerindia 1 (éditorial), p. 15$18,1976$.

TASTEVIN, Constantin. Le fleuve Muru: Ses habitants, croyances et moeurs Kachinaua. La Géographie, XLIII \& XLIV, p. 403-422 \&p. 14-35, 1925.

WEBER, Ingrid. Um copo de cultura: Os Huni Kuin (Kaxinawá) do rio Humaitá e a escola. Rio de Janeiro: Núcleo Transformações Indígenas, 2006. 